The Foundling Hospital and Its Music

Author(s): F. G. E.

Source: The Musical Times and Singing Class Circular, Vol. 43, No. 711 (May 1, 1902), pp.

304-311

Published by: Musical Times Publications Ltd.

Stable URL: http://www.jstor.org/stable/3369303

Accessed: 20-06-2016 03:17 UTC

\footnotetext{
Your use of the JSTOR archive indicates your acceptance of the Terms \& Conditions of Use, available at

http://about.jstor.org/terms
}

JSTOR is a not-for-profit service that helps scholars, researchers, and students discover, use, and build upon a wide range of content in a trusted digital archive. We use information technology and tools to increase productivity and facilitate new forms of scholarship. For more information about JSTOR, please contact support@jstor.org.

\footnotetext{
Musical Times Publications Ltd. is collaborating with JSTOR to digitize, preserve and extend access to The Musical Times and Singing Class Circular
} 


\section{THE FOUNDLING HOSPITAL AND ITS MUSIC.}

More than one hundred and fifty years have come and gone since good Thomas Coram founded the 'Hospital for the Maintenance and Education of Exposed and Deserted Young Children in Lamb's Conduit Fields,' which we know as The Foundling. The kind-hearted old mariner little thought when, in I 739, he petitioned King George II. for a charter, that the Institution established under his beneficent auspices would be associated, and so worthily associated, with the great master of music known the world over as George Frederick Handel. The scheme of the Hospital buildings, erected between I 740 and I 750, on the then outskirts of London, included a chapel. Handel was quick to perceive that the chapel-of which we give, by special and kind permission of the Committee, an interesting drawing as it was in Handel's day-would be the very place for a great music-making. The Minutes of the Committee furnish most interesting and fresh information concerning Handel and his noble benefactions to the Foundling Hospital.

The first entry must be given in full :-

$$
\text { At the Hospital, May } 7, \text { I } 749 \text {. }
$$

Mr. Handel being present and having generously and charitably offered a performance of vocal and instrumental musick to be held at this Hospital, and that the money arising therefrom should be applied to the finishing the chapel of the Hospital.

Resolved - That the thanks of this Committee be returned to $\mathrm{Mr}$. Handel for this his generous and charitable offer.

Ordered-That the said performance be in the said Chapel on Wednesday, the $24^{\text {th }}$ inst., at eleven in the forenoon.

Resolved-That the gentlemen present and the rest of the members of the General Committee, or any two of them be a Committee to carry into execution this intention with the advice and direction of Mr. Handel.

Resolved - That George Frederick Handel Esq. in regard to this his generous proposal be recommended to the next General Court to be then elected a Governor of this Hospital.

Brownlow, in his history of the Hospital, says that Handel was actually made a Governor at this time, and this statement has been copied over and over again. But the generous-hearted musician, while much appreciating the proposed honour of being elected a Governor, informed the Secretary that he 'desired to be excused therefrom, for that he should serve the charity with more pleasure in his way than being a member of the Corporation.' However, as we shall presently see, the Court of Governors overruled Handel's objection by electing him a Governor in the following year (I75O), more especially as an acknowledgment of his gift of an organ to the chapel, but doubtless not without consideration of the initial and memorable performance of I 749 .

The advertisements stated that the performance would be in the chapel, 'which will be sash'd and made commodious for the purpose.' The obsolete word 'sash'd' evidently refers to the light framework inserted in the windows to hold the glass.
We also learn from the newspapers of the day that the performance was postponed from May 25 to 27 , " the alteration being necessary for the reception of some persons of high distinction.' The following notice, from the Gentleman's Magazine, informs us on that 'high distinction' point and other matters of no less interest :-

$$
\text { SATURDAy } 27^{\text {th. }} \text { May, I } 749 \text {. }
$$

The P. and Prss. of Wales, with a great number of persons of quality and distinction, were at the chapel of the Foundlings' Hospital ; to hear several pieces of vocal and instrumental musick, compos'd by George Frederick Handel, Esq. ; for the benefit of the foundation.

I. The musick for the late fire-works, and the anthem on the peace.

2. Select pieces from the oratorio of Solomon, relating to the dedication of the Temple; and

3. Several pieces composed for the occasion, the words taken from Scripture, and applicable to the charity, and its benefactors.

There was no collection, but the tickets were at half-aguinea, and the audience above a thousand, besides a gift of $2000 \mathrm{l}$ from his majesty, and $50 l$ from an unknown.

No. 3 consisted of the anthem, ' Blessed are they that consider the poor,' which Handel composed specially for the Foundling, the manuscript of which, partly in his autograph, and partly in the handwriting of Christopher Smith, is one of the treasures of the Hospital.

The Geneval Advertiser, one day before the concert, stated that 'above one hundred voices and performers have engaged to assist on that laudable and charitable occasion'; and we also learn that the performance was 'most complete and solemn.' The London Evening Post, of May 27-30, I 749, referred to the 'several curious pieces of music composed by Mr. Handel,' and, in regard to the audience, ' a prodigious concourse of the Nobility and Gentry.' The thanks of the Committee of the Hospital to Handel and his coadjutors were conveyed in these terms, as recorded in the Minutes of May 31 :-

That the thanks of the Committee be returned to George Frederick Handel Esq. for the generous assistance he gave to this charity by his most excellent performance of musick on Saturday last; and that $\mathrm{Mr}$. Handel be desired to return the thanks of this Committee to the performers who voluntarily assisted him upon that occasion.

That the thanks of this Committee be returned to the Master of the Children of the King's Chapel for his and their attendance at the said performance.

That the treasurer do pay the secretary $f 50$ for $\mathrm{Mr}$ Handel to dispose of in such manner as he shall think fit.

According to the invaluable Minutes-there is nothing like first-hand information in these matters - a year was not allowed to elapse before the Committee resolved, on February 7, I $7 \mathbf{5}_{0}^{\mathbf{9}}$

That it be referred to the Sub-committee to consider of the manner of opening the Chapel, and having a performance of musick, and that they do consult $\mathrm{Mr}$. Handel thereupon.

That the Secretary do wait upon Mr. Handel to propose a performance of musick and voices on Tuesday, the first of May next [1750]. 


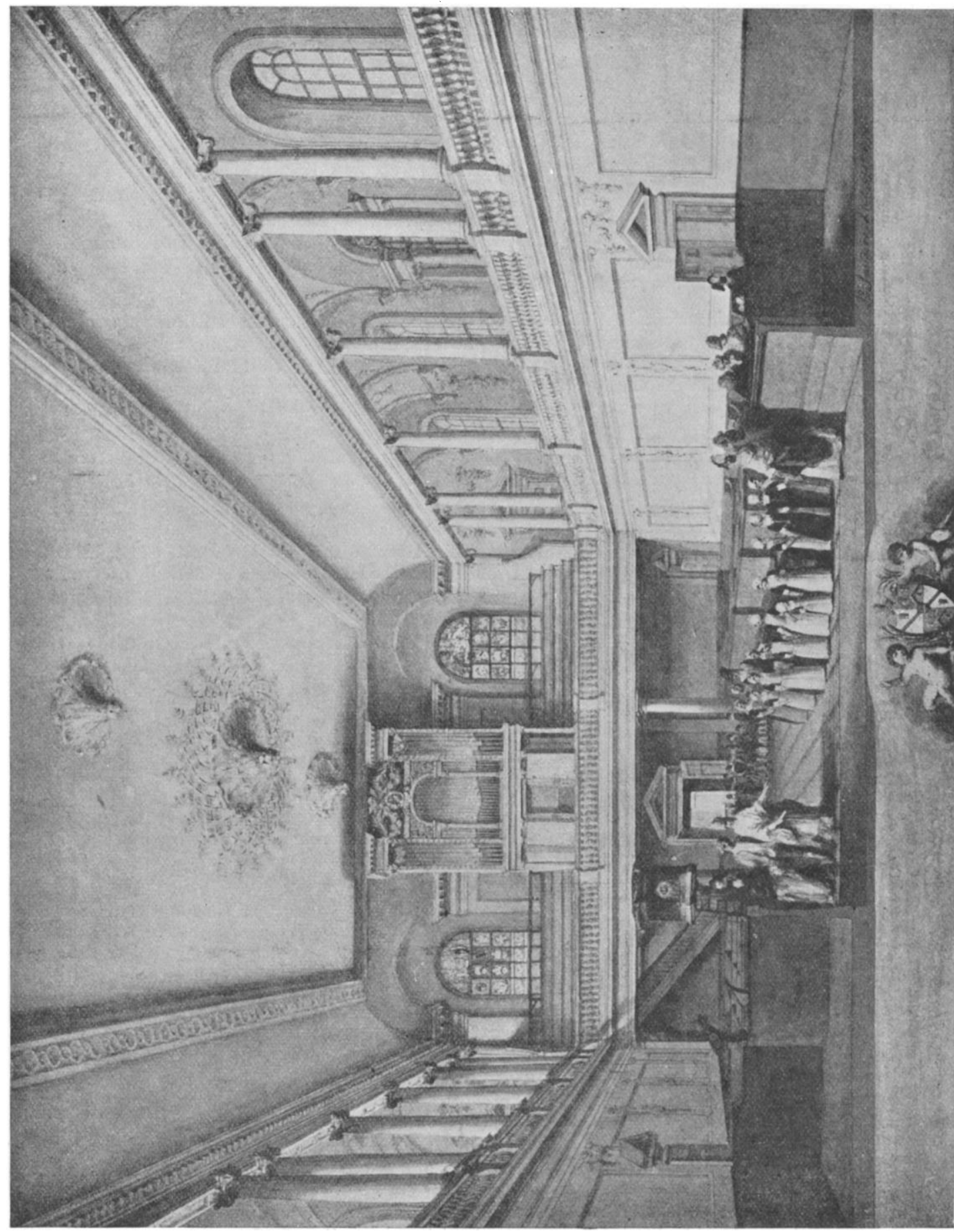

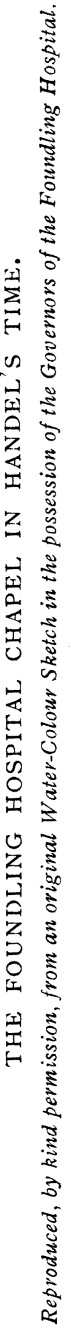


The good-natured composer at once, and doubtless very heartily, fell in with the proposal, as the Minutes of April I8, I750, contain the following interesting information :-

The Secretary acquainted the Committee that $\mathrm{Mr}$. Handel had agreed to the following Advertizement to be published for his intended Performance.

Hospital for the Maintenance and Education of Exposed and Deserted Young Children in Lamb's Conduit Fields April I8th, I750.

George Frederick Handel Esq. having presented this Hospital with a very fine Organ for the Chapel thereof, and repeated his offer of assistance to promote this Charity; on Tuesday the First Day of May I75o at Twelve o'clock at noon, Mr. Handel will open the said Organ; and the sacred Oratorio called 'Messiah' will be performed under his direction.

Tickets for this performance are ready to be delivered by the Steward at the Hospital, at Batson's Coffee-House in Cornhill, and White's Chocolate House in St. James's Street, at half a Guinea each.

Ordered-That the said Advertizement be published in the Daily Advertizer, on Friday next, and every day after to Tuesday the first of May; Twice a week in the General Advertizer, twice a week in the Gazetteer, and twice a week in some evening papers.

The 'advertizements' duly appeared with, however, the following important addition: "There will be no collection'! As to the performance -and it is interesting to find the use of the term 'open the organ'--one newspaper of the day actually stated that 'upwards I,200 Hundred (!) Persons of Distinction' were present, while another, nearer the truth, referred to ' $\mathrm{a}$ great Appearance of Nobility and Gentry to hear the oratorio.' The identical receipt for the payment of the performers at the organ-opening is still preserved at the Hospital. Here is a transcript :-

May 4, I750. Hospital for the maintenance and Education of exposed and deserted young children, Thirty-five pounds for the performers in the oratorio of 'Messiah' on Tuesday, the I $^{\text {st }}$ inst., in the Chapel of the said Hospital, to be distributed and paid over pursuant to the Directions of my Master, George Frederick Handel Esq. by $£ 35$. o. o.

Christopher Smith.

The net proceeds of this 'Messiah' organ opening performance amounted to the sum of $£ 728$ 3s. 6d. 'Peter, Mr. Handel's servant,' was paid one guinea, but Mr. Beard, the solo tenor, and Mr. Christopher Smith, returned their feestwo guineas and one guinea respectively - to the funds of the charity. On the following day (May 2) Handel attended the meeting of the Committee, when he most generously offered to give a second performance of his great oratorio. An advertisement in the daily papers furnishes us with full particulars:-

A computation was made of what number of persons the Chapel of the Hospital would conveniently hold, and no greater Number of Tickets were delivered to hear the Performance there on the First instant. But so many Persons of Distinction coming unprovided with tickets and pressing to pay for tickets, caused a greater number to be admitted than were expected; and some that had tickets not finding room going away. To prevent disappointment to such persons, and for the further promotion of this charity, this is to give notice that George Frederick Handel, Esq., has generously offered that the sacred oratorio called 'Messiah' shall be performed again under his direction, in the chapel of this Hospital, on Tuesday the $5_{5}$ th instant, at twelve of the clock at noon; and the tickets delivered out, and not brought in on the Ist instant, will then be received.

Note.-There will be no collection; and it is hoped, that no Persons will take it ill, that they cannot be admitted without Tickets (General Advertiser, May 4, I750).

An interesting Minute of April I8, I750, must not be omitted. The Treasurer reported:-

That Mr. Hudson had offered to present the Hospital with Mr. Handel's picture, and that Mr. Handel had consented to sit for it.

Mr. Hudson was duly thanked; but what has become of that particular Hudson portrait? It is not in the Hospital collection; perchance it is one of several of Handel by that artist which are scattered in various places.

The Court Minutes of the Governors-who met quarterly - of May 9, I750, record the following appreciation of Handel's benevolence:-

George Frederick Handel, Esq., having presented this Hospital with an Organ, for the Chapel thereof.

Resolved-That the thanks of this General Court be severally given to the said Mr. Handel .... for the same, which the Vice-President accordingly did.

Resolved - That they [Handel and six other benefactors] be now Balloted for, to be Elected Governors and Guardians of this Hospital, and the said George Frederick Handel [and others] were accordingly elected by Ballot.

This shows that Handel was not elected a Governor till the year I750, and not in I749, as is generally stated.

And now as to the organ given by Handel to the Foundling Hospital. Extracts from the Minutes of the Committee meeting held on May 2, I750, at which, by-the-way, Handel was present, read thus:-

Mr. Handel acquainting the Committee that Dr. Morse, of Barnet, had not finished the organ for the Chapel of this Hospital pursuant to the contract he made with him in July last for that purpose,

Ordered - That the Secretary do write to Dr. Morse to press his finishing the organ for immediate use, and that he may find able persons to have as many stops therein as he can, for chorus's, before Tuesday, the ${ }_{1} 5^{\text {th }}$ inst.

On May 30, Dr. Morse attended the Committee meeting and promised to proceed without delay; and on February 6 in the following year, it is recorded that Dr. Morse had 'delivered all the pipes,' and that he was paid $\ell^{20}$ 'for the diapason stop.'

But who was 'Dr. Morse, of Barnet'? All authorities, including William Russell, organist of the Foundling, I80I-I3, state that the Handel presented organ was built by Parker, or Glyn and Parker. (Rockstro gives the name as 'Parkes,' 
and this error has been copied in the article on goes that Handel heard the organ built by Handel in the Dictionary of National Biography.) Parker in Poynton Church, Cheshire, on the Parker was an organ-builder, residing at Salford. Lancashire border, and that he was so pleased Dr. Henry Watson (who has most kindly made with it that he selected Parker to supply an enquiries for the purpose of this article) finds him instrument at his (Handel's) expense for the as Richard Parker, 'at the Sign of the Organ,' in Foundling Hospital Chapel. But, from his Chapel Street, Salford, the identical thoroughfare researches made on the spot, Dr. Watson is in which Dr. Watson himself resides! Glyn strongly of opinion that the Parker organ heard may have been a London partner. The story by Handel was not in Poynton Church, as that

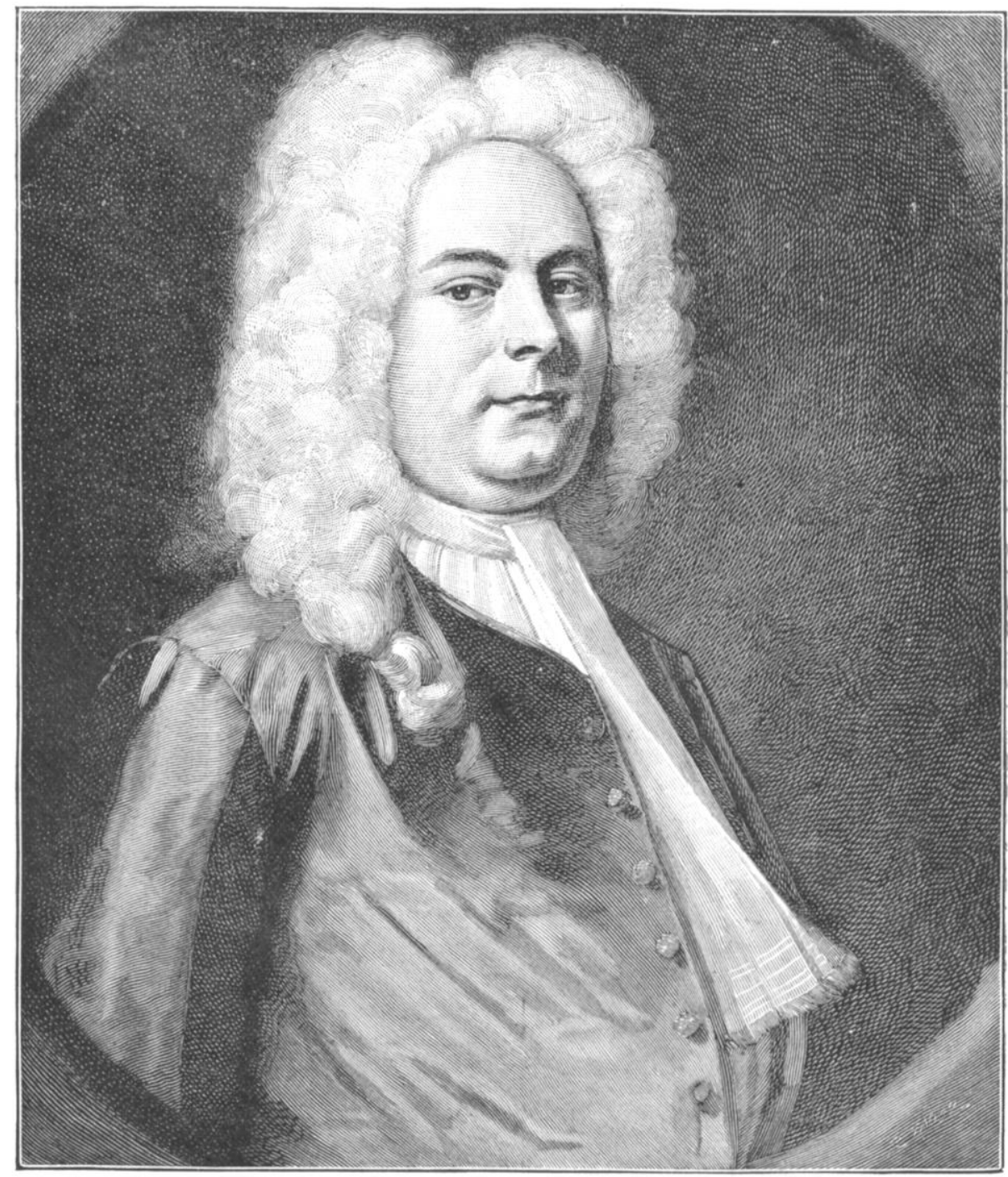

GEORGE FREDERICK HANDEL, Eso.

A GOVERNOR OF THE FOUNDLING HOSPITAL.

From the painting by Denner, in the possession of $M r$. Alfred Littleton.

sanctuary was not consecrated till I 789 , but According to the invaluable manuscript the decayed old instrument, still standing, collection of organ matter made by the late but unplayable, in Adlington Hall, two miles Dr. E. J. Hopkins, and now in the possession of from Poynton, the residence of the Legh family. the present writer, the Foundling instrument Handel was a frequent guest of Colonel built by Parker was a very remarkable one, more Charles Legh, the Lord of Adlington, and it especially by reason of its profusion of quarter was without doubt that he made his acquaintance tones. Here is the information, which, it should of Parker's work under the hospitable roof of his be added, Dr. Hopkins copied from a manuscript host, the Colonel. account made early in the last century by 
William Russell, the fifth organist of the Foundling, who regularly played on the Parker instrument :-

This organ originally contained sixteen notes in the octave; that is to say, in addition to the seven naturals, and the five unequally tempered short keys, - E flat, C sharp, G sharp, and B flat,-it also had four others which sounded D sharp, D flat, A flat, and A sharp. These supplementary notes were not furnished with extra keys, after the manner of Father Smith's organ in the Temple Church ; but certain mechanism was provided whereby they could be substituted for those ordinarily associated with the short keys. The external part of this mechanism consisted of a number of handles or levers, each working in a horizontal cutting, and having three places of rest. The following diagram shows the arrangement of these handles located in the neighbourhood of the Draw-stops :-

Left hand side.

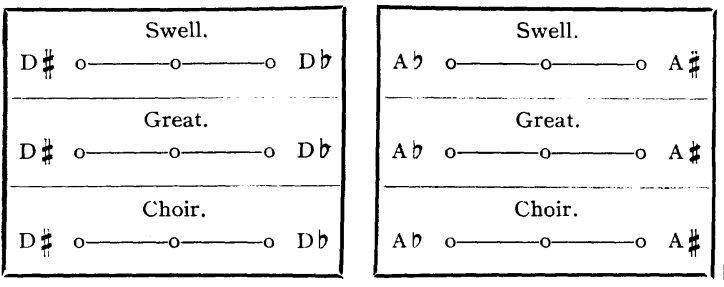

If a piece of music in the key of $E, 4$ sharps, were about to be played, the handle on the left hand side was moved to its extreme left, with the result that $D$ sharp would be substituted for the normal $E$ flat. If, on the contrary, a piece in 4 flats were going to be performed, the handle was shifted to the extreme right, when a D flat would be brought on in place of the usual $\mathrm{C}$ sharp. All the other handles effected similar alterations. Five handles belonged to a single set of keys. When the handles were placed in the middle of the slides or cuttings, the organ was like the common or unequally tempered organ of the period.

The original specification of the Foundling Organ was as follows :-

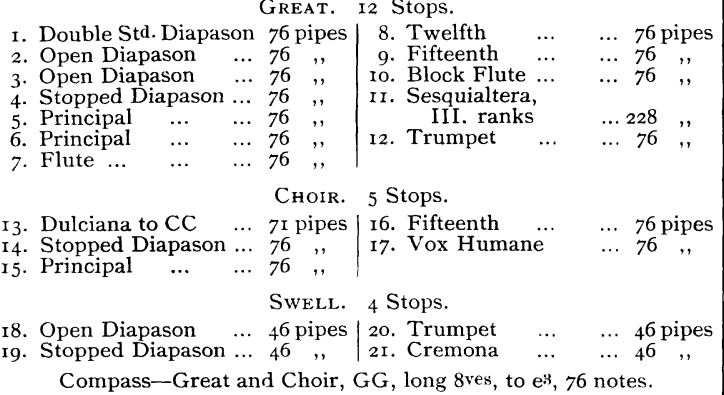

Compass-Great and Choir, GG, long 8ves, to e3, 76 notes. Swell-Fiddle $g$ to $\mathrm{e}^{3}, 46$ notes.

Dr. Hopkins (or Russell) adds :-

Handel evidently did not favour much mixture-work for on comparing the above with the Temple Organ it will be seen that to less than half the quantity of mixture, he disposed twice the amount of unison and octave-work, i.e., two Open Diapasons and two Principals. There was also a second 'Large Fifteenth' or Block Flute.

The keyboard of the old organ is still preserved : it has black natural and white sharp keys.
As to whether Parker or Morse built the first organ erected in the Foundling Hospital Chapel, is a mystery that has yet to be solved. This we shall endeavour to do.

Year after year, until his death, Handel gave a performance of his 'Messiah' at the Foundling Hospital, in aid of its funds. It is not necessary to refer to these music-makings in detail, but one or two features of interest, derived from the Minute Book and old newspapers of a century and-a-half ago, deserve to be mentioned. The Gentleman's Magazine of May, I75I, says :-

The Oratorio of 'Messiah' was again performed at the Foundling hospital under the direction of Geovge Frederick Handel Esq., who himself play'd the organ, for the benefit of the charity; there were above 500 coaches besides chairs, $\&$ c., and the tickets amounted to above 700 guineas.

The General Advertiser furnishes this additional information: "A Voluntary on the Organ was played by Mr. Handel, which met with universal Applause'-and this in the chapel! It is interesting to find from the Minutes that in this year, Bernard Gates, Master of the Children of the Chapel Royal, returned to the Treasurer the sum of $£ 5$ 7s. od., being the amount of the fees (six guineas) paid to the King's choristers for singing in two performances, ' deducting nineteen shillings for their coach hire.' That Mr. Bernard Gates was heartily thanked goes without saying. A year later the General Advertiser of April I 8, I 752, stated :-

We hear that the Ladies who have tickets for the oratorio of 'Messiah' at the Foundling Hospital, this Day the I8th inst., intend to go in small Hoops, and the Gentlemen without Swords, to make their Seats more convenient to themselves.

On that occasion ' the number of tickets given out' was i200, each at Ios. 6 d.

An extract from the Minutes concerning this I 752 performance must be quoted. Does it not speak for itself ? :-

A most noble and grand audience, who expressed the greatest satisfaction at the exquisiteness of the composition, the completeness of the performance, and the great benevolence of $\mathrm{Mr}$. Handel.

At the next performance (in I753) of the 'Messiah,' we learn that 'the inimitable composer thereof, in the organ concerto, play'd himself a voluntary on the fine organ he gave to that chapel.

We must now pass on to the year I754, when it was reported to the Committee that Handel intended to assign his rights in the 'Messiah' to the Hospital authorities! This, however, could only be done by an Act of Parliament, which the Governors lost no time in proceeding to obtain. A petition was duly drawn up in these terms:-

That in order to raise a further sum for the benefit of the said Charity, George Frederick Handel, Esq., hath been charitably pleased to give to this corporation a composition of music, called 'The Oratorio of the 
" Messiah," ' composed by him the said George Frederick Handel, reserving to himself the liberty only of performing the same for his own benefit during his life: and whereas the said benefaction cannot be secured to the sole use of your petitioners except by the authority of Parliament, your petitioners, therefore, humbly pray, that leave may be given to bring in a bill for the purposes aforesaid.

When one of the Governors submitted this petition to Handel, he soon discovered that the Committee of the Hospital had built on a wrong foundation. No sooner had Handel read the document than, bursting into a rage, he exclaimed: 'Te Deivil! for vat sal de Foundling put mein oratorio in de Parlement! -Te Deivil! mein music sal not go to de
Parlement.' 'The Minutes of the Hospital Committee do not record this outburst of unparliamentary language, but more temperately state that 'the same did not seem agreeable to Mr. Handel for the present.'

The minutes of April 7, I756, record:-

Mr. Handel having renewed his charitable offer of performing the Oratorio 'Messiah,' at the Chapel of this Hospital,

Resolved - That the said performance be on Wednesday, the Igth of next Month, and that the Secretary do write a letter to Mr. Handel to return him Thanks and acquaint him with the Day fix'd upon, and to desire that he will please to give people Directions to $\mathrm{Mr}$. Smith the Organist of this Hospital, in relation thereto.

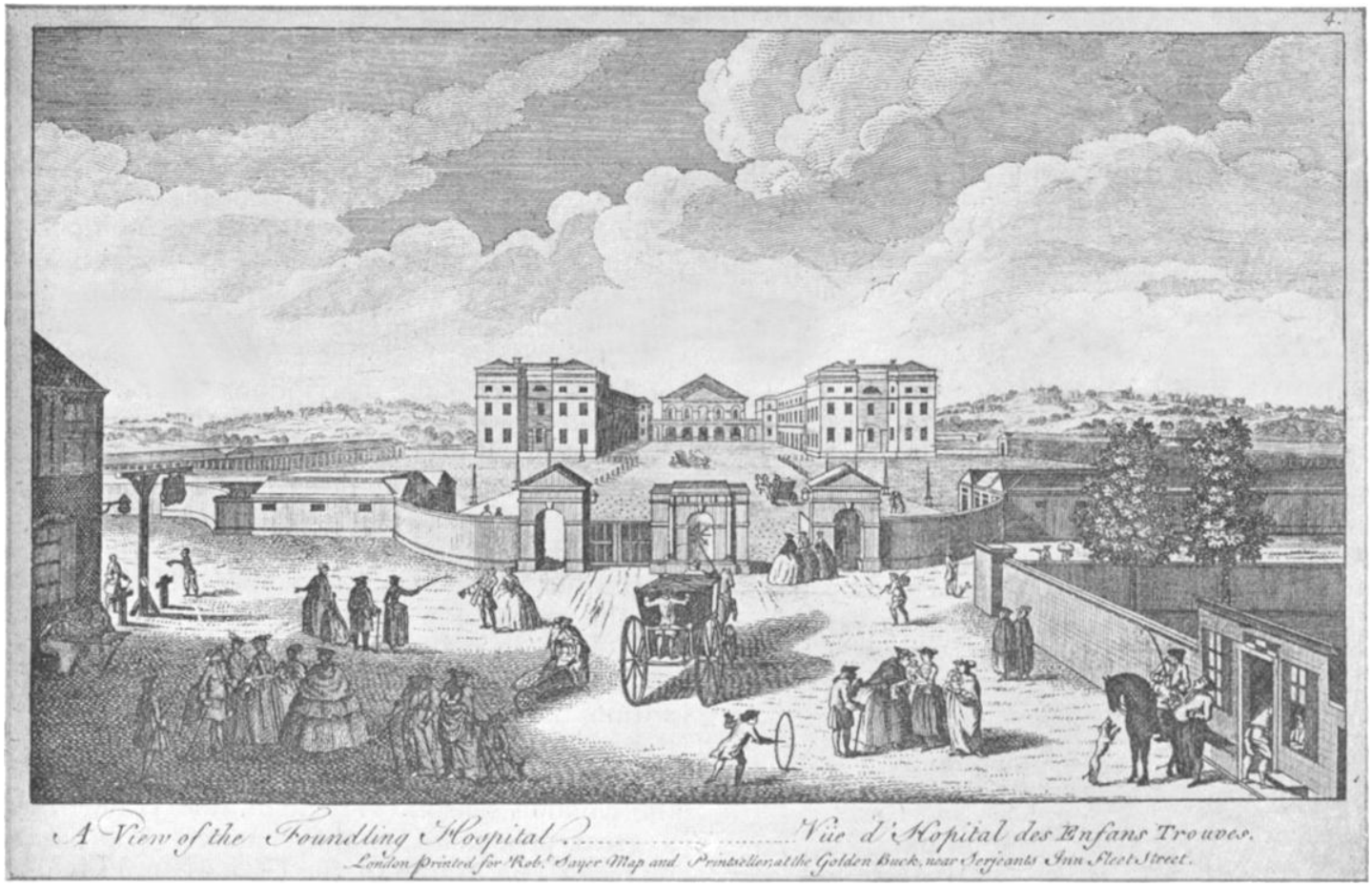

THE FOUNDLING HOSPITAL IN THE OLDEN TIME.

(From a print in the possession of Mr. H. Davan Wetton.)

Mr. Moffatt, the organ tuner (or 'turner'), seems that the usual annual performance of the 'Messiah,' to have given some trouble. The Minutes record ' under the direction of George Frederick that he was discharged, and that (on March 9, I 757) Handel, Esq.,' would take place ; but the next the Committeeissue of that journal records:-

Resolved-That John Crang, Organ Builder, at the White Lyon in Wych Street, near $\mathrm{S}^{\mathrm{t}}$ Clements, be organ turner (sic) in the room of $\mathrm{Mr}$. Moffatt at the same salary of five Guineas a year, to begin the $25^{\text {th }}$ of this Month.

Last Saturday and not before died at his house in Brook Street Grosvenor Square, that eminent master of musick George Frederick Handel Esq.

The performance, however, took place--Handel could not have wished it otherwise-on May 3, A touching incident connected with Handel's under the direction of his pupil and amanuensis, noble connection with the Foundling Hospital has John Christopher Smith. Smith's bill of the now to be recorded. On Saturday, April I 4, I 759, expenses of that performance has fortunately the Public Advertiser contained an advertisement been preserved, and it clearly proves that Handel 
employed horns in his orchestral accompaniments balance of chorus and orchestra-only six soprano to the 'Messiah.' Through the kindness of the chorus singers; the name of Walz, Handel's Committee of the Hospital, we are permitted to print this most interesting document :-

A list of the Performers in the Oratorio called 'Messiah' at the Foundling Hospital, May $3^{\text {rd, }}$ I759.

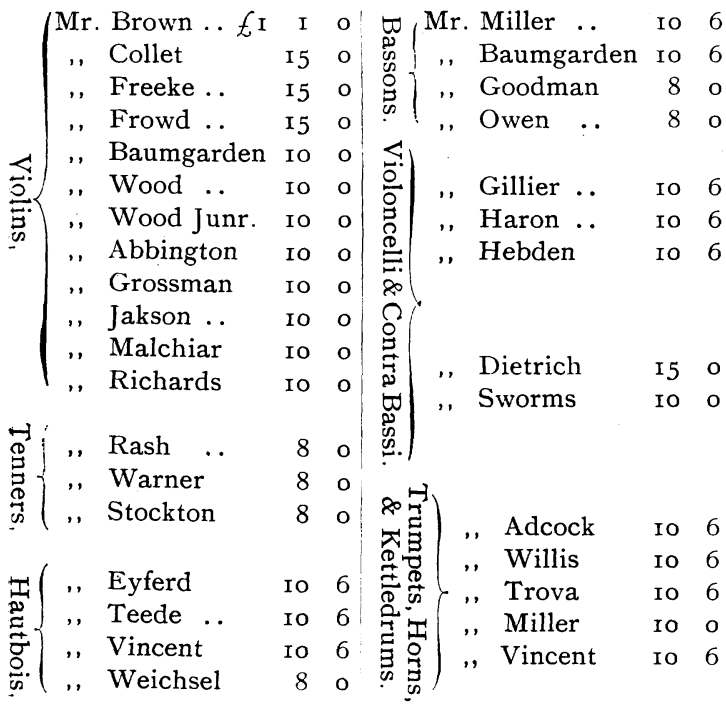

$£$ I7 15

\section{Singers.}

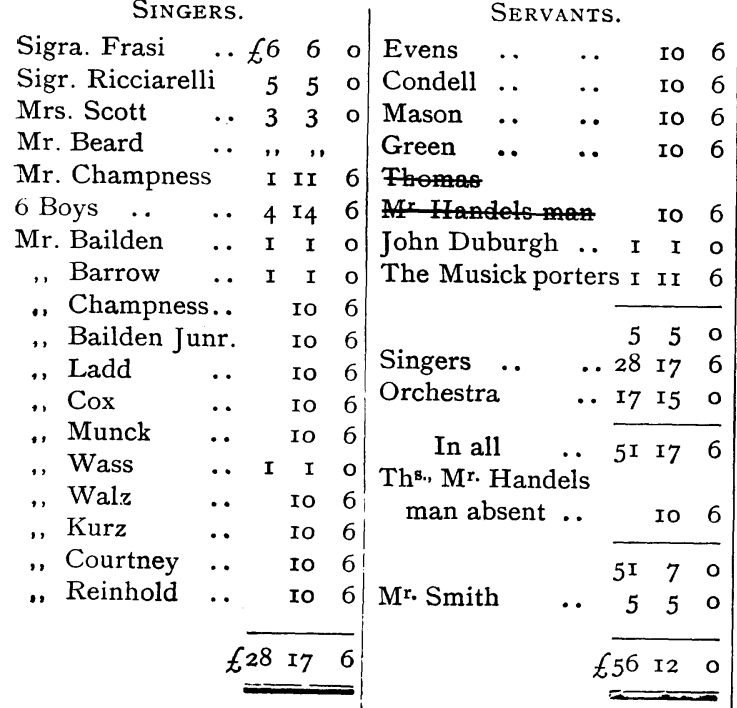

May Ioth, 1759 , Recl, of Mr. Lancelot Wilckinson, the sum of fifty-six pounds twelve shills, in full of all Demands, by me

Christopher Smith. cook, as one of the basses in the chorus; and, pathethic beyond words to express, the scoring through of ' Thomas, Mr. Handels man.'

Handel did not forget the Hospital in his will He bequeathed to the charity 'A fair copy of the score and all the parts of my Oratorio called the 'Messiah.' The former, in three oblong volumes, and in the handwriting of Christopher Smith, has been carefully preserved. The parts, of even greater importance, seem to have been overlooked until Mr.H. Davan Wetton, the present organist, discovered them eight years ago, in an old cupboard close to the organ, where they had probably lain undisturbed and unknown for many a day.

The 'Messiah' performances were annually continued for several years under the direction of John Christopher Smith, Handel's factotum, and John Stanley, the blind organist. According to Burney, the total amount accruing to the Institution from performances of the 'Messiah' 10 6 alone reached the splendid total of $E$ ro,299, of which $£ 6,935$ was realised during the composer's lifetime-a magnificent result of his warm-hearted generosity. It may be mentioned that, among the 'tokens' still preserved at the Hospital, of former children, is a large coin-like piece of metal bearing the inscription, 'Maria Augusta Handel, born April I5, I 758,' the explanation being that it was often the custom in former years to name a poor deserted wee bairnie after one of the Governors.

A digression to another artistic path may be permitted in referring to some other treasures in the possession of the Foundling Hospital. And here it may be mentioned that the fine collection of pictures, prints, sculpture, \&c., within the walls of the Institution gave rise to the origin of the Royal Academy Exhibition of paintings, now so important a feature of the London season. Hogarth, like Handel, was a great benefactor to the charity. His famous picture 'The March of the Guards to Finchley' hangs on the walls of the Secretary's office. The story goes that Hogarth, being unable to sell it to any one purchaser, resolved to do so by lottery, and gave the Hospital, of which also, like Handel, he was a Governor, I 67 tickets which remained unsold, and it was one of these which gained the picture. A fine life-size picture of Captain Thomas Coram, the founder of the Hospital, the portrait which Hogarth 'painted with most pleasure,' adorns the walls of the beautifullyproportioned Board Room, the very apartment in which Handel and Hogarth, as members of the governing body, must have fraternised. This room, with its richly-decorated ceiling, contains

There are several features of special interest eight interesting medallions of the principal in this bill of costs-e.g., the fees paid to the London hospitals contemporary with the Foundprincipal singers (Frasi and others) and the ling, one of which is from the brush of players in the band; the voluntary help of Gainsborough. A Raffael cartoon, ' The murder Mr. Beard, he chief tenor of Handel's day- of the innocents'; an altar-piece in the one who must have loved the composer; the chapel, 'Christ presenting a little child,' 
painted by West; and a bust of Handel by Roubiliac - the same artist who designed the famous Vauxhall statue, now in the possession of Mr. Alfred Littleton, was made-are among the other numerous art-treasures in the Hospital. Hogarth's punch-bowl may also be seen, and there is a letter from Charles Dickens, dated 'February 26, I840,' in which he regrets having to give up his pew in the chapel, by reason of his removal, ' as we miss it [the service] very much,' he says. Handel's tuning-fork, oil paintings of Weber (by Cawse), and Sir George Smart as a young man-the two portraits discovered by Mr. Davan Wetton-add interest to a very interesting collection of art possessions.

Further consideration of the history of the music at the Foundling Hospital Chapelincluding the performance of Gounod's 'Redemption,' under Mr. H. Davan Wetton's careful direction, on the I $5^{\text {th }}$ ult.-must, by considerations of space, be held over until next month; but full acknowledgment must not be deferred of the facilities afforded to us through the kindness of Mr. Robert Grey, Treasurer, Mr. W. S. Wintle, Secretary, and Mr. H. Davan Wetton, Organist, in the preparation of this article on the music of the Foundling Hospital.

$$
\text { (To be continued.) }
$$$$
\text { F. G. E. }
$$

HANDEL'S MESSIAH :

\section{PREFACE TO THE NEW EDITION.}

By Professor Prout.

I.

So many editions of Handel's greatest and most popular oratorio exist that the appearance of a new one seems to require some explanation. To give such explanation is the object of the present Preface.

There are two chief reasons which have induced the publishers to decide upon issuing a new and revised edition of the 'Messiah.' These are-first, the corruptness of the text of all existing editions, ${ }^{*}$ and secondly, the unsatisfactory condition of the additional accompaniments in general use. Each of these reasons it will be necessary to discuss in some little detail.

It is extremely doubtful whether any other great musical work exists, the text. of which is in even approximately so corrupt a condition as that of the 'Messiah.' Only those who have carefully collated the published editions, whether of the full or vocal score, with the original manuscript (now readily accessible through the photolithographed facsimiles), or with contemporary transcripts made by Handel's amanuensis, Christopher Smith, can have the least idea either of the number or character of the mistakes which are to be found in many movements.

* It is probable that the edition prepared by the late Dr. Chrysander for the German Handel Society will contain a correct text; but this edition, though stated to be in
This will be seen when, later in this Preface, the text of the present edition is discussed.

The deplorable condition of the existing text is not difficult to account for, though the explanation is hardly to the credit either of the critical acumen or the care of successive editors. The earliest edition of the score, published for the first time in a complete form by Randall and Abell, the successors of Walsh, and known as the Walsh Edition,* is, like most of the first editions of Handel's works, extremely incorrect. Arnold's edition, which was the next to follow, appeared in 1789 , and is little more than a reprint of that which had preceded; the internal evidence proves clearly that it had never been collated with the original manuscript. Subsequent editors have, with hardly an exception, copied from these early editions, or from one another. Of all the numerous editions consulted in the preparation of the present volume, not a single one is even approximately correct in its text. Surely it is high time that musicians should at least have the opportunity of knowing what Handel actually wrote!

The other reason for a new edition is the unsatisfactory state of the additional accompaniments commonly used. Into the general question of the necessity for additional accompaniments it is not needful to enter at great length. It must however be pointed out that, from various causes, it is all but impossible in the present day to reproduce the effect of one of Handel's oratorios as it was given under his own direction. The balance of chorus and orchestra is, owing to the growth of chorus singing and the great size of our modern choral societies, absolutely different from what it was in Handel's time; the composition of the orchestra itself, and therefore its tone-quality, are not at all the same; the organs in our chief concert-rooms are far larger; and the harpsichord, to which Handel allotted so important a part in the accompaniment of his songs, has vanished altogether from the orchestra. That, under quite exceptional conditions, it is possible to give an approximate reproduction of Handel's chorus and orchestra was proved by the performance of 'Alexander Balus,' given at the Conference of the Incorporated Society of Musicians at Scarborough, in January, I90o; but the attempts made from time to time by our musical societies to give Handel's music as he meant it to be given must, however earnest the intention, and however careful the preparation, be foredoomed to failure from the very nature of the case. With our large choral societies, additional accompaniments of some kind are a necessity for an effective performance; and the question is not so much whether, as how they are to be written.

The additional accompaniments to the 'Messiah' used in this country, and I believe also abroad, are those known as Mozart's, for

* Schoelcher, in his 'Life of Handel' (p. 273), gives 1758 as the date of the first complete edition of the 'Messiah,' but it appeared in date of the fir
the year $176 \%$. 